J. Product. \& Dev., 18(1):23-35(2013)

\title{
THE ANTIMICROBIAL AND ANTIOXIDANT EFFECTS OF AQUOUS THYME AND SUMAC EXTRACTS IN REFREGIRATED MINCED BEEF MEAT
}

\author{
Faten Y. Ibrahim * and Sh. M. El-Shehawy ${ }^{*}$,** \\ * Food Industries Dept., Fac. of Agriculture, Mansoura University, Egypt. \\ ** Biology Dept., College of Applied Sciences, Umm Al-Qura University, \\ Makkah, KSA.
}

\section{ABSTRACT}

The objective of this study was to evaluate the antimicrobial and antioxidant effects of 0,10,20,30 and 40\% thyme and sumac hot water extract added to minced beef meat after populated with pathogenic bacteria and stored at $4 \pm 1 .{ }^{\circ} \mathrm{C}$ for 6 days. Total Phenolic and total flavonoids compounds in thyme and sumac extracts were determined by HPLC. There antioxidant activity was screened using DPPH radical scavenging methods. The antimicrobial activities assessment was tested by agar wells-diffusion method and minimum inhibitory concentration (MIC) using broth media.

The obtained results showed that the inhibition percentage values ranged from 35.9 to 39.6 and 25.2 to $37.6 \%$ for thyme and sumac extracts, respectively. Also, The results showed that $40 \%$ extract had the most antibacterial activity against all studied bacteria in agar wells-diffusion. Thus, this level only was further examined in broth media at levels (3 to 6\%). In minced beef meat the used levels were (4, 5 and $6 \%$ ) because the slight effects of the 3\% concentration. Bacillus subtilis was found to be the most sensitive bacteria to sumac extract showing a MIC of 3.5\%. Both S. typhimarium and E. coli were coming at the second rank with $4 \%$ while St. aureus ranked the last with MIC of 4.5\%. In addition, the sumac extract inhibitor activity against all studied bacteria was better than thyme extract in broth media. In minced beef meat samples, both thyme and sumac water extracts were effect on all studied bacteria during storage period.

So that, thyme and sumac spices, which are traditionally used as astringent agents, have promising inhibitory effects against pathogenic bacteria and could be considered as natural food preservatives.

Keywords: Antimicrobial, Spices, DPPH, minced beef meat, thyme and sumac. 


\section{INTRODUCTION}

Food-borne diseases are still a major concern in some developing countries. The world awareness on chemical preservatives in food industries is now reflected by the consumers' opinions. So, they focus on natural GRAS "generally regarded as safe" preservatives (Dillon and Board, 1994). Spices are herbal products which have been safely used by people around the world to impart desirable flavors and aromas to the local foods. Natural extracts from spices have been long used in meats as flavoring agents (Kim et al., 1995). It looks that there has been a natural selection for spices as food additives. These spices are mainly originated from plants grown in the tropical regions with wide effects on food-borne bacteria. Several of these spices and their essential oil extracts have been reported to posses' antimicrobial activities e.g. garlic, savory, basil, laurel, mint, cumin, onion, sumac and thyme (Delgado, et al., 2004). Plant essential oils (EOs) also exhibit antimicrobial activity by interfering and destabilizing the operation of the phospholipids bilayer of the cell membrane, enzyme systems, and genetic material of bacteria (Kim et al., 1995). The EOs antimicrobial activity depends on the type, composition and concentration of the spice or the derivatives, the type and concentration of the target microorganism, the composition of the substrate, the processing and the storage conditions (Marino et al., 2001).

Thyme (Thymus vulgaris L.), an aromatic plant of the Labiateae family, has been long used in foods for culinary purposes. Thyme and oregano species are rich in EOs characterized by a notable antimicrobial activity; for this reason, these substances can be used to delay or inhibit the growth of pathogenic or spoilage microorganisms. Thyme EO contains more than 60 ingredients, most of which posses important antioxidant and antimicrobial properties (Baranauskiene et al., 2003). The most important compounds of thyme EO are the phenols thymol (44-60\%) and carvacrol (2.2-4.2\%), which constitute the major and more active constituents (Di Pasqua et al., 2005).

Sumac is the common name for a genus (Rhus) that contains over 250 individual species of flowering plants in the family Anacardiaceae (USDA 2007). In general, sumac can grow in non-agriculturally viable regions and various species have been used by indigenous people for medicinal and other purposes, suggesting potential for commercializing the bioactivity of these plants without competing for food production land uses (Van Wyk and Wink, 2004). Sumac has an acidic sour taste due to its indigenous organic acids and is mainly sprinkled on various kinds of kebabs. In traditional medicine sumac is used as astringent agent (Wetheritlt and Pala, 1994).

Sumac (Rhus coriaria L.) is one example, which is widely used in Turkey and the Middle East. The fruits are red colored and contain one seed. Its dried and ground leaves have been used as a tanning agent due to their high tannin content. Previous phytochemicals studied of this plant reported that its 
leaves contained flavones, tannins, anthocyanins, and organic acids (Mavlyanov et al., 1997). However, it is the fruit of the plant that is typically consumed as spice after drying and grinding. Other reports indicated that sumac has antimicrobial activity with limited information on its antioxidant activity and potential as a new source of antioxidative substances, but these claims were not fully substantiated (Candan and Sokmen, 2004).

Raw meat can be easily contaminated by microorganisms and support the growth of pathogens, leading to serious food-borne diseases. Refrigeration is the most common preservation method of raw meat and meat products. In order to extend the shelf life of refrigerated foods, synthetic additives may be used. Since the safety of synthetic additives has been questioned in recent years, consumers increasingly demand the use of natural products as alternative preservatives in foods (Solomakos et al., 2008).

Therefore, the aim of this work was to study the antimicrobial effect of hot water extract of thyme and sumac on pathogenic bacteria and possibility of using them as naturally antimicrobial agents in refrigerated minced beef meat.

\section{MATERIALS AND METHODS}

\section{Materials:}

Thyme (Thymus vulgaris L.), sumac (Rhus coriaria L.), beef meat, were purchased from local market in Mansoura City, Egypt. Chemicals and media used for following examinations were purchased from El-Gomhoria Company, Mansoura branch, Egypt. Pathogenic bacteria, Gram-positive bacteria (Staphylococcus aureus , Bacillus subtilis) and Gram-negative bacteria (Salmonella typhimarium, E-coli HMY13 ), were obtained from Dairy Department, Faculty Agriculture, Mansoura, Univeristy, Egypt.

\section{Methods:}

\section{Extract preparation:}

The herbs were milled using laboratory miller to fine powder. Powder of herbs samples $(0,10,20,30$ and $40 \mathrm{~g})$ were soaked in $100 \mathrm{ml}$ boiling tap water for $15 \mathrm{~min}$ at $70{ }^{\circ} \mathrm{C}$ in water bath followed by cooling and filtration through filter paper.

\section{Determination of total phenolic compounds and total flavonoids:}

Total phenol content was determined according to the method described by Danial and George (1979). The concentration of flavonoids in the methanol plant extracts was measured spectrophotometrically at $440 \mathrm{~nm}$ (Zhisen 1999).

\section{Radical scavenging assay DPPH:}

The antioxidant activity of thyme and sumac extracts were assessed by their ability to scavenging 2, 2-diphenyl-1-picrylhydrazyl stable free radicals 
(DPPH). The DPPH assay was performed as described by Miler and RiceEvans (1997).

\section{Assessment of antimicrobial activities:}

Agar wells-diffusion method was used and the antimicrobial test was performed according to the method of Wan et al. (1998) with some modification. Briefly, $0.5 \mathrm{ml}$ of fresh overnight cultures of the tested bacteria (containing $10^{6}-10^{7} \mathrm{cfu} / \mathrm{ml}$ ) was spread on nutrient agar in sterile Petri dishes $(9 \mathrm{~cm})$. Wells were created using a $8 \mathrm{~mm}$ cork borer. Each well was filled with $30 \mu 1$ of thyme and sumac hot water extract, $(0,10,20,30$ and $40 \% \mathrm{w} / \mathrm{v})$ samples. Afterwards, the dishes were lifted for $1 \mathrm{~h}$ at $4 \pm 1{ }^{\circ} \mathrm{C}$ to allow better diffusion of the extracts into the media prior to incubation at $37^{\circ} \mathrm{C}$ for $24 \mathrm{~h}$. The inhibition zones were observed as no growth of bacteria and the inhibition activity was recorded in millimeter $(\mathrm{mm})$. All experiments were conducted in duplicate and the results are expressed as average values of inhibition.

\section{Minimum inhibitory concentration (MIC):}

Dilutions of sumac and thyme extracts with concentration of 1 to $6 \%$ (w/v) were prepared from its water extract $40 \%$. Bacterial cultures were diluted in Muller Hinton broth from the stock of $10^{8} \mathrm{cfu} / \mathrm{ml}$ before they were added to the extract preparations. Final concentration of bacteria in individual tubes was $5 \times 10^{5} \mathrm{cfu} / \mathrm{ml}$. Control tubes contained no extract. After $24 \mathrm{~h}$ of incubation at 37 ${ }^{\circ} \mathrm{C}$ the test tubes were examined for possible growth and minimum inhibitory concentrations (MIC) of each extract were determined as the lowest concentration that ended with no growth. (Andrews, 2001).

\section{Preparation of beef meat samples:}

Major meat was obtained from beef carcasses. The outer surface of each muscle was sterilized by immersion in ethanol 95\% (v/v) and then burning to evaporate the ethanol residual from the meat surface, as previously described by Greer and Jones (1991). After the aseptic removal of the outer surface, the inner core of the sterile meat was aseptically minced utilizing a sterile steel meat grinder. Prior to meat inoculation with pathogen bacteria and the addition of thyme and sumac water extract, minced meat was also examined for any contamination by the tested pathogen bacteria. Sterile minced beef samples ( 25 g) were placed in stomacher bags and inoculated with single strain (ca $10^{4}$ $\mathrm{cfu} / \mathrm{g}$ ). The inoculated samples were homogenized in a stomacher for $2 \mathrm{~min}$ at room temperature to ensure proper distribution of the pathogen. Following homogenization, thyme and sumac water extract were added to the inoculated samples. Treatment of the samples included no addition (control), addition of water extract at 4,5 and $6 \%$ (v/w) from water extract $40 \%$ were examined only ,because the high level than it provide unacceptable organoleptic of minced meat. To attained uniform distribution of the added compounds, treated meat 
samples were further homogenized in stomacher as previously described. All stomacher bags with samples from all treatments were wrapped and stored under aerobic conditions at $4 \pm 1^{\circ} \mathrm{C}$ for 6 days in refrigerated storage. Microbiological analysis of samples for populations pathogen bacteria were carried out at 0,3 and 6 days.

\section{RESULTS AND DISCUSSION}

\section{Total Phenolic and total flavonoid content in thyme and sumac:}

Total Phenolic in thyme and sumac were determined and expressed as gallic acid equivalents and total flavonoid as quercetin content $(\mathrm{mg} / 100 \mathrm{~g})$. The results showed the total phenolic content in thyme is higher than sumac (Table 1). It was 818 and $706 \mathrm{mg} / 100 \mathrm{~g}$ as gallic acid in thyme and sumac, respectively. This result was higher than the gallic acid content $(505 \mathrm{mg} / 100 \mathrm{~g})$ of hot water extract of sumac which was previously found by (Kosar et al., 2007). Flavonoids are the most common group of polyphenolic compounds in the human diet, and they are found ubiquitously in plants. Quercetin is a wellknown plant-derived flavonoid that may have anti-inflammatory and antioxidant properties (Davis, 2009). The observed results in this study showed that the total flavonoid content in sumac was higher than thyme (Table 1). These data are in accordance with Ercan and Ekrem (2011) who reported that the total flavonoid content in water extract of sumac was $600 \mathrm{mg} / 100 \mathrm{~g}$.

Table 1. Total Phenolic and total flavonoid content $(\mathrm{mg} / 100 \mathrm{~g})$ in thyme and Sumac extracts:

\begin{tabular}{|c|c||c|}
\hline Herbs & Total phenolic & Total flavonoid \\
\hline \hline Thyme & 818 & 486 \\
\hline Sumac & 706 & 826 \\
\hline
\end{tabular}

Antioxidant activity as inhibition \% DPPH of thyme and Sumac extracts:

Thyme and sumac extracts were tested for antioxidant activity using the DPPH assay. The radical scavenging activity of natural extracts depends greatly on concentration as it is shown in Table 2 and Figure 1.The radical scavenging ability increased with the increasing amount of different extracts. Inhibition percentage values ranged from 35.9 to $39.6 \%$ and 25.2 to $37.6 \%$ for thyme and sumac extracts, respectively. These results were in agreement with Ercan and Ekrem (2011). They reported that the percentages of DPPH radical scavenging activity of different concentrations $(10,20$, and $30 \mu \mathrm{l} / \mathrm{ml})$ of methanol extract of sumac were $15.8,23.2$ and $41.2 \%$ respectively. It could be stated that scavenging effects is not limited to phenolic and flavonoid compounds only. 
Table 2. Antioxidant activity as inhibition \% of thyme and sumac methanol extracts as determined by the DPPH assay:

\begin{tabular}{|c||c||c|}
\hline Concentration $(\mu \mathrm{g} / \mathrm{ml})$ & Thyme $(\%)$ & Sumac $(\%)$ \\
\hline 20 & 35.9 & 25.2 \\
\hline 40 & 37.5 & 27.3 \\
\hline 60 & 37.9 & 29.8 \\
\hline 80 & 38.9 & 35.1 \\
\hline \hline 100 & 39.6 & 37.6 \\
\hline
\end{tabular}

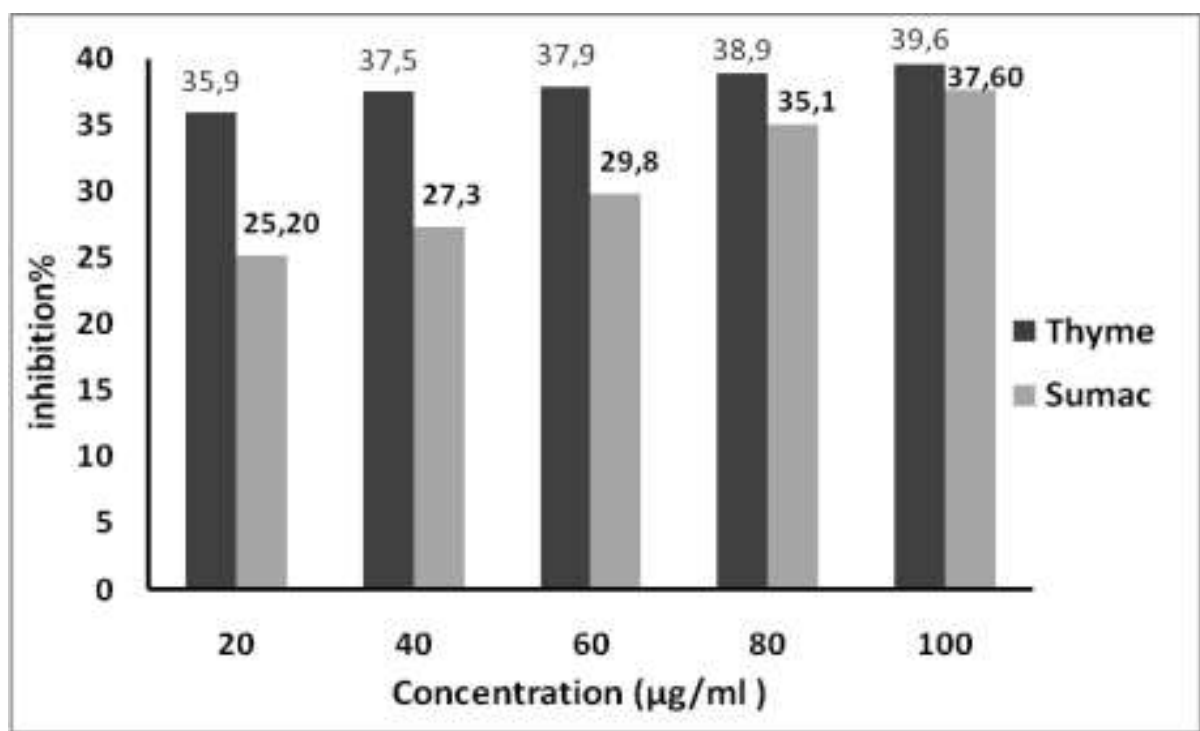

Figure 1. Antioxidant activity as inhibition \% of thyme and sumac methanol extracts as determined by the DPPH assay.

The activity also comes from the presence of other antioxidant secondary metabolites in the extracts which directly or indirectly contribute to the activity.

\section{Minimum inhibitory concentration (MIC)}

MIC depends on many factors such as temperature, time of incubation, and size of inoculums (Friedman et al., 2002). The minimum inhibitory concentration (MIC) of thyme and sumac extract were determined against four pathogenic bacteria including Gram-positive and Gram-negative bacteria (Table 3). B. subtilis was found to be the most sensitive bacteria to sumac extract showing a MIC of 3.5\%. Both S. typhimarium and E. coli were coming at the second rank with $4 \%$ while St. aureus ranked the last with MIC of $4.5 \%$. A previous study on antimicrobial effect of sumac conducted by Dolaz et al. (2002) was also reported higher sensitivity of B. megaterium to sumac. 
Table 3. Minimum inhibitory concentration (MIC) of thyme and sumac hot water extract $(v / v)$ from extract $40 \%$.

\begin{tabular}{|c|l|c|c|}
\hline \multicolumn{2}{|c|}{ Microorganisms } & \multicolumn{2}{c|}{ Herbs } \\
\cline { 2 - 4 } & St. aureus & 5.0 & Thyme extract(\%) \\
\cline { 2 - 4 } Gram-positive & B. subtilis & 4.0 & 4.5 \\
\hline \hline \multirow{2}{*}{ Gram- negative } & S. typhimarium & 6.0 & 3.5 \\
\cline { 2 - 4 } & E-coli HMY13 & 4.0 & 4.0 \\
\hline \hline
\end{tabular}

These results are also in accordance with those of Nasar-Abbas and Kadir Halkman (2004) who also found that B. cereus was the most sensitive strains to sumac. They have reported MICs of $0.32 \%$ and $0.49 \%$ of sumac against $B$. cereus and St. aureus, respectively compared to higher MIC values against Gram-negative bacteria. Furthermore, thyme showed less but uniform inhibitory effect on both Gram-positive and Gram-negative bacteria compared to sumac. Inhibitory effects were augmented with increase in extract concentrations.

\section{Diameters of inhibition zones ( $\mathrm{mm}$ ):}

The inhibition zone diameter depends on the ability of the test substance to uniformly diffuse through an agar medium (Friedman et al., 2002). The inhibition effect of thyme and sumac extract used at different concentrations against various microorganisms using well diffusion methods are presented in Table 4 and Figures 2 and 3. Both spices showed inhibition activity against both Gram-positive as well as Gram-negative bacteria and inhibitory effects were augmented with increase in extract concentrations. S.typhimarium and $B$. subtilis were the most sensitive food-borne bacteria, while E. coli and St. aureus were the most resistant. These results showed that sumac extract was better than thyme extract against all strains. The reason of these results may be due to the acidic of sumac where $\mathrm{pH}$ was 3.27 , while $\mathrm{pH}$ of thyme was 5.49. These results are agreement with Wetheritlt and Pala ( 1994). They reported that sumac has an acidic sour taste due to its indigenous organic acids.

Table 4. Diameters of inhibition zones $(\mathrm{mm})$ around wells filled with thyme and Sumac hot water extracts at different concentrations

\begin{tabular}{|c|c|c|c|c|c|c|c|c|c|c|c|}
\hline \multirow{3}{*}{\multicolumn{2}{|c|}{ Microorganisms }} & \multicolumn{10}{|c|}{ Diameter of inhibition zone (mm) } \\
\hline & & \multicolumn{5}{|c|}{ Thyme extract (\%) } & \multicolumn{5}{|c|}{ Sumac extract (\%) } \\
\hline & & $\mathbf{0}$ & $\mathbf{1 0}$ & 20 & 30 & 40 & $\mathbf{0}$ & $\mathbf{1 0}$ & 20 & 30 & 40 \\
\hline \multirow{2}{*}{$\begin{array}{l}\text { Gram- } \\
\text { positive }\end{array}$} & St. aureus & 8 & 12 & 14 & 15 & 18 & 8 & 16 & 21 & 24 & 26 \\
\hline & $B$. subtilis & 8 & 13 & 14 & 18 & 21 & 8 & 19 & 22 & 23 & 27 \\
\hline \multirow{2}{*}{$\begin{array}{l}\text { Gram- } \\
\text { negative }\end{array}$} & S. typhimarium & $\overline{88}$ & 14 & 18 & 20 & 22 & 8 & 16 & 21 & 24 & 29 \\
\hline & E-coli HMY13 & 8 & 13 & 15 & 18 & 19 & 8 & 18 & 20 & 23 & 26 \\
\hline
\end{tabular}




\section{Antimicrobial activity in treated minced beef meat:}

The inhibitory effects of thyme and sumac water extract at (4.0, 5.0 and $6.0 \% \mathrm{v} / \mathrm{w}$ ) from extract $40 \%$ on pathogenic bacteria in minced beef meat samples stored at $4.0 \pm 1.0^{\circ} \mathrm{C}$ for 6 days, are shown in Table 5. During storage, population of the pathogen in the negative control was lowest. On the other hand, the positive control was the highest pathogenic bacteria numbers. In the studied samples, treating with thyme and sumac extract at different levels, population with tested bacteria decreased during storage compared with positive control.

The results showed that St. aureus was the most sensitive bacteria followed by $S$. typhimarium and $E$.coli to thyme and sumac extract in minced beef meat samples. In contrast, $B$. subtilis was the most resistant in minced beef meat. These results were differed compared to MIC results. These different may be revered to the effect of the chemical composition of minced beef meat as it mentioned by Snyder (1997). He reported that, the inhibitory effect of sumac may be reduced in foods as compared with pure cultures. Also, he found that the fat, protein, water and salt contents of food improve microbial resistance as it has been observed that higher levels of spices are necessary to inhibit growth in food than in culture media.

Conclusively, it could be concluded that thyme and sumac hot water extracts (at level 6\% (v/w) from water extract $40 \%=2.4 \mathrm{~g} / \mathrm{Kg}$ ) could be a natural source of antioxidants and antimicrobial agents in reducing the total contamination level of meat and meat products, beside their effect against food pathogen bacteria.

\section{REFERENCES}

Andrews, J. M.(2001). Determination of minimum inhibitory concentrations. Journal of Antimicrobial chemotherapy, 48(Suppl.1):5-16.

Baranauskiene, R.; Venskutoni, S. P. R.; Viskelis, P. and Dambrauskiene, E. (2003). Influence of nitrogen fertilizers on the yield and composition of thyme (Thymus vulgaris). Journal of Agriculture and Food Chemistry,51: 7751-7758.

Candan, F. and Sokmen, A. (2004). Effects of Rhus coriaria L. (Anacardiaceae) on lipid peroxidation and free radical scavenging activity. Phytotherapy Research, 18: 84-86.

Danial. J. A and George. S. M. (1979). Peach seed dormancy in relation to indigenous inhibitors and applied growth substances, J. American Society. Hort. Sci., 27:651-654. 
Davis, J. M. ; Murphy, E. A., Carmichael, M. D., and Davis, B. (2009). Quercetin increases brain and muscle mitochondrial biogenesis and exercise tolerance. American J. of Physiology: Regulatory, Integrative and Comparative Physiology, 296(4), 1071-1077.

Delgado, B. ; Palop, A.. ; Fernandez, P. S. and Periago, P. M. (2004). Combined effect of thymol and cymene to control the growth of Bacillus cereus vegetative cells. European Food Research and Technology, 218,188-193.

Di Pasqua, R. ; De Feo, V. ; Villani, F.and Mauriello, G., (2005). In vitro antimicrobial activity of essential oils from Mediterranean Apiaceae, Verbenaceae and Lamiaceae against foodborne pathogens and spoilage bacteria. Ann. Microbiol. 55, 139-143.

Dillon, V. M. and Board, R. G. (1994). Future prospects for natural antimicrobial food preservation systems. In V. M. Dillon (Ed.), Natural antimicrobial systems and food preservation (pp. 297-305). Wallingford, UK: CAB.

Dolaz, M. ; Golcu, A. ; Kevser Dagci, E. and Serin, S. (2002). Antimicrobial activities of Sicilian sumach (Rhus coriaria). In Proceedings of ICNP ، Trabzon, Turkey, pp. 79-82.

Ercan , B. and Ekrem , K.(2011). Evaluation of reducing power and radical scavenging activities of water and ethanol extracts from sumac (Rhus coriaria L.) Food Research International 44 2217-2221

Greer, G. G., and Jones, S. D. M. (1991). Effects of lactic acid and vacuum packaging on beef processed in a research abattoir. Canadian Institute of Food Science and Technology J. 24:161-168.

Friedman, M. ; Henika, P.R. and Mandrell, R.E. (2002). Bactericidal activities of plant essential oils and some of their isolated constituents against Campylobacter jejuni, Escherichia coli, Listeria monocytogenes, and Salmonella enterica. J. Food Prot., 65: 1545-1560.

Kim, J. ; Marshall, M. R. and Wei, C.I. ( 1995). Antibacterial activity of some essential oil components against five foodborne pathogens. J. Agric. Food Chem. 43, 2839-2845.

Kosar, M. ; Bozan, B. ; Temelli, F. and Baser, K. H. C. (2007). Antioxidant activity and phenolic composition of sumac (Rhus coriaria L.) extracts. Food Chemistry, 103:952-959.

Marino, M.; Bersani, C. and Comi, G. (2001). Impedance measurements to study the antimicrobial activity of essential oils from Lamiaceae and Compositae. International J. of Food Microbiology, 67:187-195

Mavlyanov, S. M.; Islambekov, Sh. Yu. ; Karimdzhanov, A. K. and Ismailov, A. I. (1997). Anthocyanins and organic acids of the fruits of some species of sumac. Chemistry of Natural Compounds, 33: 209. 
Miler, N. J. and Rice-Evans,C.A.(1997). Factors influencing the antioxidants activity determined by ABTS radical cations assay.Free Rad.Res.26:195199.

Nasar-Abbas, S. M. and Kadir Halkman, A. (2004). Antimicrobial effect of water extract of sumac (Rhus coriaria L.) on the growth of some foodborne bacteria including pathogens. International J.of Food Microbiology, 97, 63-69

Snyder, O.P. (1997). Antimicrobial Effect of Spices and Herbs. www.hitm.com/Documents/Spices.html.Octoper (2012)

Solomakosa,N.; Govarisa,A.; Koidisb, P. and Botsoglou, N. (2008).The antimicrobial effect of thyme essential oil, nisin, and their combination against Listeria monocytogenes in minced beef during refrigerated storage. Food Microbiology, 25: 120-127.

USDA (2007). United States Department of Agriculture. Germplasm resources information network. Beltsville, MD, USA: Agricultural Research Service. <http:// www.arsgrin.gov/npgs/aboutgrin.html>

Van Wyk, B. E. and Wink, M. (2004). Medicinal plants of the world. Portland,OR, USA: Timber Press.

Wan, J. ; Wilcock, A..and Conventry,M.J. (1998).The effect of essential oils of Basil on the growth of Aeromonas hydrophila and pseudomonas Juorescens. J. Appl. Microbiol.84, 152.

Wetheritlt, H. and Pala, M. (1994). Herbs and spices indigenous to Turkey. In G. Charalambous (Ed.), Developments in Food Sciences (Vol. 34). Spices, Herbs and Edible Fungi (pp. 285-307). Amsterdam: Elsevier.

Zhisen, J . (1999). The determination of flavonoid contents in mulberry and their scavenging effects on superoxide radicals. Food Chemistry.64: 555559. 
التأثير المضاد للميكرويات و الاكسده للمستخلص المائي لكلاً من الزعتر الزئر المبرد والسماق في اللحم البقرى المفروم المبرد.

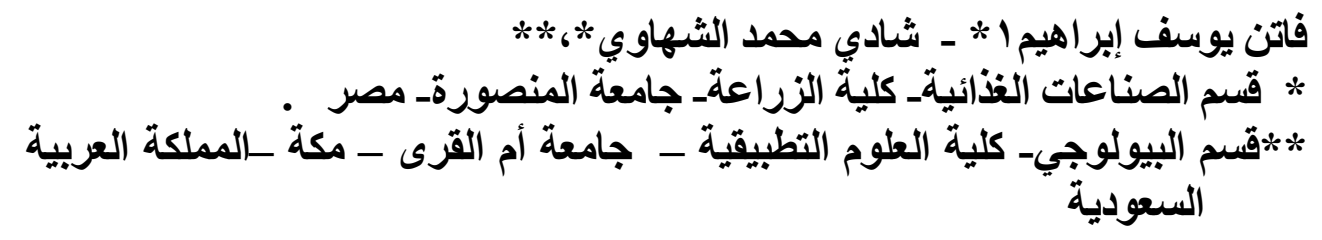

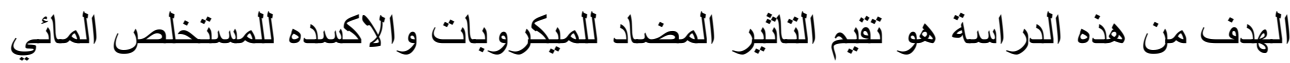

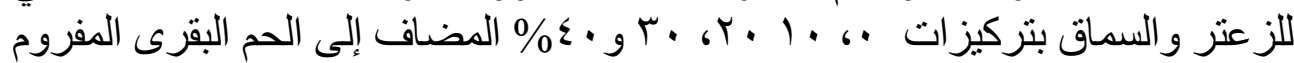

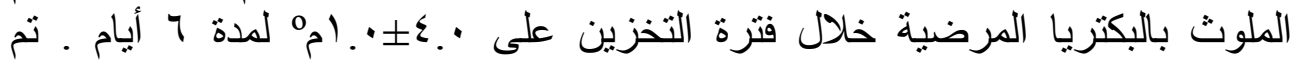

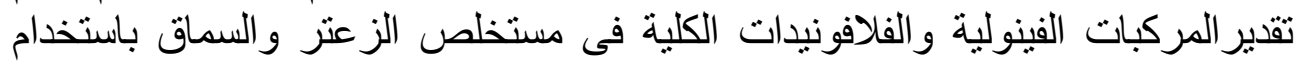

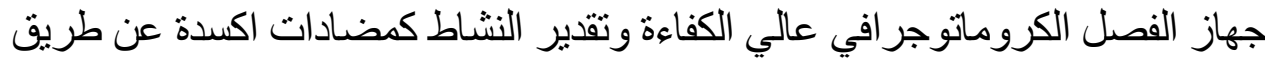

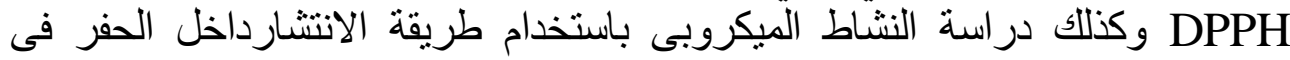

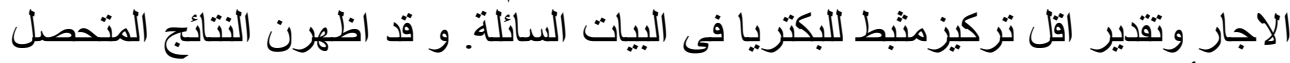

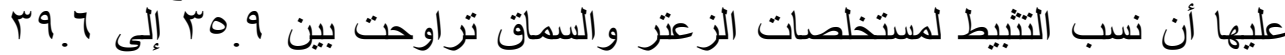

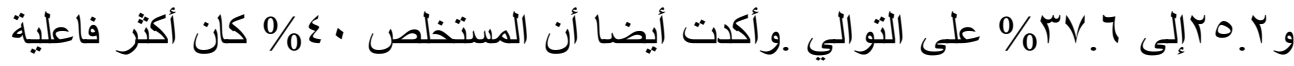

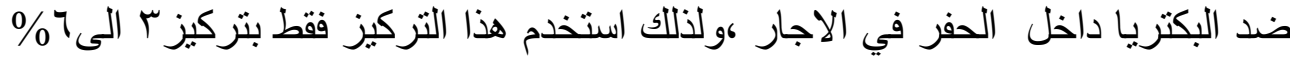

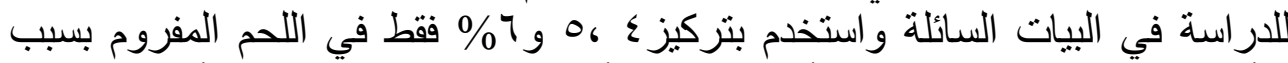

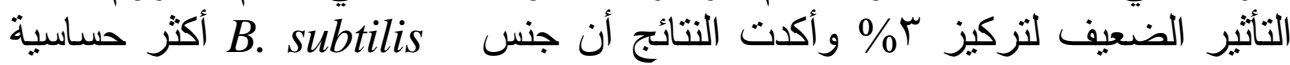

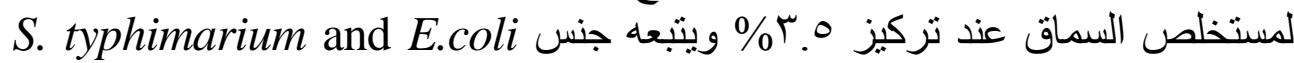

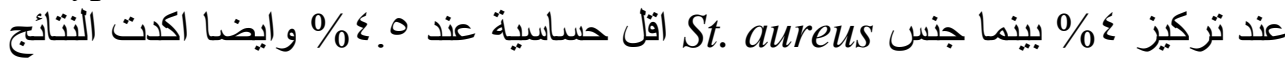

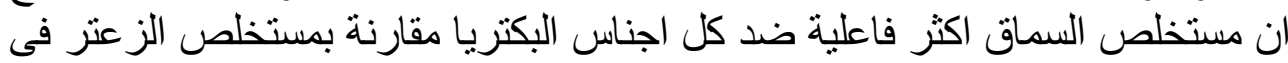

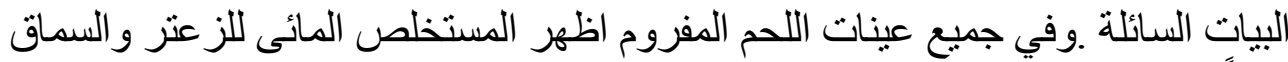

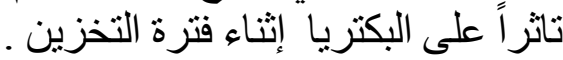

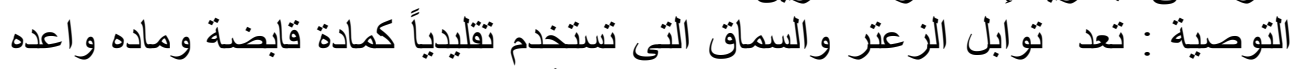

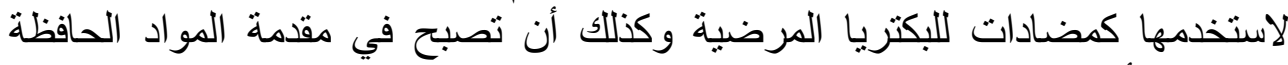

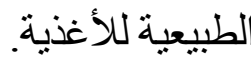

ـ DPPH الكلمات الدالة : المضاد للميكروبات ـ التو ابلـ الحم البقرى المفروم ـ الز عتر

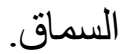

